\title{
Cost-benefit analysis of flight extended operations (ETOPS) for Garuda Indonesia airways
}

\author{
Ratna Purwaningsih ${ }^{1}$, Lakshita Pritandari ${ }^{1, *}$, Haryo Santoso ${ }^{1}$ \\ ${ }^{1}$ Industrial Engineering Department, Diponegoro University, J1 Prof Soedharto, SH, Tembalang, \\ Semarang, 50275 Central Java, Indonesia
}

\begin{abstract}
Garuda Indonesia reducing the flight cost used flight extended operations (ETOPS). ETOPS can reduce travel time and fuel consumption. The cost-benefit analysis was conducted to compare the flight between NON ETOPS flight and ETOPS flight Cengkareng - Perth - Cengkareng route. Net benefit of ETOPS flight is USD 1.212.863 and NON ETOPS is USD 1.154.894. Cost structure analysis was conducted to identify the percentage of flight cost component. The biggest percentage of cost was direct flight cost. It is equal to $49,53 \%$ for route Cengkareng - Perth NONETOPS and $47,70 \%$ for ETOPS. While for the route Perth - Cengkareng NON-ETOPS and ETOPS have the same amount of $46.03 \%$. Based on the results of the cost-benefit analysis, it is evident that the ETOPS flight can reduce the fuel cost, although the flight requires trained pilots. Contribution of the paper is brief describe on the structure of revenue and expenditure items in airways business. The structure is specific, different from other transportation business.
\end{abstract}

Keywords: ETOPS, fuel, cost-benefit analysis, cost structure

\section{Introduction}

Determination of public transport fares require the right policy to bridge the interests of passengers as consumers and employers as providers of public transport services. Many factors affect the transport tariffs, such as public purchasing power, the cost of maintenance, spare parts price, fuel prices, facilities and infrastructure [1]. Air transportation has specific structure on revenue and expenditure items which not much discuss on scientific publication. Technical knowledge is needed to obtain the data of revenue and expenditures of airways business.

Garuda Indonesia is the largest airline in Indonesia. Garuda Indonesia airlines carry more than 25 million passengers annually, serve flights to more than 40 domestic destinations and 26 international destinations. Garuda Indonesia has prepared various aircraft to meet the needs of consumers for international flights, such as Airbus Industries A330-300, Boeing 737-800, and others. Boeing 737-800 is one type of aircraft with seat load factor of 162 seats, this type of aircraft can be used to travel internationally to countries such as Perth, Australia.

\footnotetext{
${ }^{*}$ Corresponding author: prita1803@gmail.com
} 
ETOPS or Extended Operations or formerly known as Extended Range-Twin Engine Operations is a technology carried out by a two-engine aircraft which has the ability to fly only with one machine for a certain period on the scope of an adequate airport (adequate airport). ETOPS can reduce the gasoline consumption due to shorter routes and leads to cost savings. Now, Garuda Indonesia is conducting a feasibility analysis of ETOPS technology for Boeing 737-800 on the Cengkareng - Perth flight route using New Generation aircraft fleet.

ETOPS flights require trained pilots, it is the investment cost. Management needs to know whether ETOPS flight is still feasible or not by calculating all cost involved. The calculation of feasibility analysis of ETOPS and NON ETOPS be reviewed by cost-benefit analysis. Cost-benefit analysis can be used to make decisions from several existing investment alternatives by reviewing the costs associated with the object under investigation. This study does a review NON ETOPS and ETOPS flights for Cengkareng Perth - Cengkareng route based on flight cost plan. The study aims to compare the resources uses for flight on structure analysis and calculating the cost-benefit analysis. The ETOPS flight used in this study was ETOPS 90 minutes.

\section{Literature review}

ETOPS or Extended Operations is an operation performed by twin-engine aircraft that have the ability to fly for 60 minutes or more with one machine in dead from the nearest airport in certain routes [2]. An adequate airport is a decent airport to serve as the launching point of the ETOPS aircraft [3]. The operating area of ETOPS is the area that the relevant aircraft can fly under the ETOPS regulation. This area is characterized by a circle centered on the adequate airports. ETOPS flights alone can save the fuel consumption and reduce the flight cost. In the USA, more than 5.5 million ETOPS twinjet flights have been logged worldwide since 1985 , and every day some 143 operators perform 1,750 more these operations set the highest standard for safe, reliable long-range flying or RLRF [4].

The cost structure is good to describe all the costs required to run a business model [5]. Identification the percentage of flight cost will help to describe the impact of saving fuel consumption on ETOPS and NONETOPS flight. Some cost component occurred while preparing the ETOPS flight. Costs are accounted for major activities, key resources, and partnerships determined. Aviation cost of differs slightly from the operational cost of manufacture companies. The cost consists of direct cost and indirect cost. Direct cost or operational costs is a cost associated with the aircraft and flight cost. The cost incurred by airlines that dependent in the intended destination, aircraft technology used, flight duration and other related aspects. Indirect cost is the cost for daily aircraft operations, aircraft and flight administration, and overhead cost (costs incurred excluding operational costs).

All these costs will be processed to get the value of the total cost. Total cost is the accumulation of all the costs required for the associated route. Total cost consists of the incremental cost of flight interrupted and $\mathrm{HO}$ administration. Flight interrupted is the cost incurred when an unavoidable delay occurs. While the administration of $\mathrm{HO}$ or administration head office is the cost of administration in the main office to handle the administration of the related routes. Morlok (1988) stated that the management of transport businesses face a very wide choice in terms of pricing and operating plans [6].

Cost-benefit analysis or CBA is a practical tool for assessing the feasibility of a project. It is important to consider the project over the long term such as reciprocity to consider the impact of a project on stakeholders [7]. CBAs on business units or those used within a company consider the commercial aspect of a project and regardless of the social effect [8]. The advantages of CBA is more efficient on using of economic resources, and the use of 
funds monitored appropriately. The disadvantages of CBA is that the impact of the project cannot be analyzed precisely and many factors influence lead to increase cost [9].

\section{Research Methods}

There are five stages to perform cost-benefit analysis calculation [10]. First, define a problem and identify possible options/alternatives. Identify problems that occur by getting information from relevant parties and start looking for solutions to solve the problems at hand. The solution offered consists of several alternatives, the best alternative will be selected based on cost-benefit analysis calculation. Second steps are determined inputs and outputs (impacts) of each option. All aspects that affect the calculation of cost-benefit analysis should be detail reviewed accordance to each available alternative.

Third steps is the valuation of the benefits and costs of each option ('net benefits'). The calculation of income and expenditure is calculated on the basis of alternatives previously reviewed, after which the profit of each alternative is calculated. Step four is to identify the 'best' option based on the calculation of each of the advantages that have been done. The last step is selected the best alternative that provides problem-solving and the benefits to be desired.

\section{Result and Discussion}

The first stage of cost-benefit analysis is defined problem and identify possible options or alternatives. Based on experienced, the demand for Cengkareng - Perth - Cengkareng route is quite attractive to consumers, indicated by high seat load factor of $75.96 \%$ for the Cengkareng - Perth route and $77.80 \%$ for the Perth - Cengkareng route. But economic conditions in 2016 are in a critical position, where the revenue of this airline has decreased compared to previous years. All program for savings already made by Airlines to increase the profit. Extended Operations or ETOPS flights on Cengkareng - Perth - Cengkareng route using Boeing 737-800 New Generation aircraft can be one of the saving programs. This stage described data of flight plan for Non-Etops and Etops based on the flight plan described in Table 1.

\subsection{Cost-benefit analysis}

The second stage of cost-benefit analysis is determining inputs and outputs of each option, means identify the revenue and expenditure structure of airways business. Based on financial statements, the revenue earned from NON-ETOPS Cengkareng - Perth flight in 2016 was USD 5,910,056 and Perth - Cengkareng was USD 6,836,053. The financial statements are recorded for each flight made by Garuda Indonesia, which consists of netincome (revenue and expenditures). The nett revenue was obtained with load factor $66.02 \%$ for Cengkareng - Perth flight and $66.40 \%$ for Perth - Cengkareng flight. Load factor is total of passengers, cargo, mail, and baggage loaded divided by the available capacity. The revenue resulted from 191 times total flights for Cengkareng - Perth and 191 for Perth Cengkareng. The calculation for ETOPS flight revenue for the same route made use the same load factor and flight frequency. A detail description of the revenue for the NonETOPS flight is listed in Table 2.

Table 2 explain the structure of revenue on airways business. The revenue of ETOPS and NON ETOPS flight give the same result. The factor give highest influence on revenue estimation is the load factor assumption. That's why the revenue of ETOPS and NON 
ETOPS should not compared. The data of revenue only needed to calculate the benefit as difference between revenue and cost.

Table 1. Comparison of Etops and Non-etops Flight information 2016

\begin{tabular}{|c|c|c|c|c|c|c|c|c|c|}
\hline & \multicolumn{4}{|c|}{ CENGKARENG - PERTH } & \multicolumn{4}{|c|}{ PERTH - CENGKARENG } & \multirow[b]{2}{*}{ uni } \\
\hline & $\begin{array}{c}\text { No } \\
\text { n-etops }\end{array}$ & $\begin{array}{l}\text { Eto } \\
\text { ps }\end{array}$ & $\begin{array}{c}\text { Gap } \\
\text { (flight) }\end{array}$ & $\begin{array}{c}\mathrm{Ga} \\
\mathrm{p} \\
\text { (year) }\end{array}$ & $\begin{array}{c}\mathrm{N} \\
\text { on- } \\
\text { etops }\end{array}$ & $\begin{array}{l}\text { Et } \\
\text { ops }\end{array}$ & $\begin{array}{c}\mathrm{Ga} \\
\mathrm{p} \\
\text { (flight) }\end{array}$ & $\begin{array}{c}\text { Gap } \\
\text { (year) }\end{array}$ & \\
\hline Payl & 15. & 15. & 4 & 83. & 17 & 17 & \multirow{2}{*}{331} & 63.5 & \multirow{2}{*}{$\mathrm{kg}$} \\
\hline oad & 144 & 578 & 34 & 328 & .179 & .510 & & 52 & \\
\hline $\begin{array}{l}\text { Dur } \\
\text { ation }\end{array}$ & 269 & $\begin{array}{r}26 \\
2\end{array}$ & 7 & $\begin{array}{r}1.3 \\
44\end{array}$ & $\begin{array}{r}27 \\
9\end{array}$ & $\begin{array}{r}27 \\
5\end{array}$ & 4 & 768 & $\begin{array}{r}\text { mi } \\
\text { nute }\end{array}$ \\
\hline \multirow{4}{*}{$\begin{array}{l}\text { Trip } \\
\text { fuel }\end{array}$} & 10. & 10. & 3 & 72. & 11 & 11 & \multirow{2}{*}{255} & 48.9 & \multirow{2}{*}{$\mathrm{kg}$} \\
\hline & 701 & 326 & 75 & 000 & .522 & .267 & & 60 & \\
\hline & 13. & 13. & 4 & 91. & 14 & 14 & 324 & 62.1 & lite \\
\hline & 590 & 114 & 76 & 440 & .633 & .309 & 324 & 79 & $\mathrm{r}$ \\
\hline \multirow{4}{*}{$\begin{array}{l}\text { Bloc } \\
\mathrm{k} \text { fuel }\end{array}$} & 16. & 16. & 4 & 82. & 15 & 15 & \multirow{2}{*}{30} & 63.3 & \multirow{2}{*}{$\mathrm{kg}$} \\
\hline & 920 & 488 & 32 & 944 & .706 & .376 & & 60 & \\
\hline & 21. & 20. & 5 & 10 & 19 & 19 & \multirow{2}{*}{419} & 80.4 & lite \\
\hline & 488 & 939 & 48 & 5.34 & .947 & .528 & & 67 & $\mathrm{r}$ \\
\hline \multirow{4}{*}{$\begin{array}{l}\text { Dist } \\
\text { ance }\end{array}$} & 1.8 & 1.7 & 9 & 18. & 1. & 1. & \multirow{2}{*}{30} & 5.76 & \multirow{2}{*}{$\mathrm{Nm}$} \\
\hline & 25 & 30 & 5 & 240 & 830 & 800 & & 0 & \\
\hline & 3.3 & 3.2 & 1 & 33. & 3. & 3. & \multirow{2}{*}{176} & 33.7 & \multirow{2}{*}{$\mathrm{Km}$} \\
\hline & 79 & 03 & 76 & 780 & 380 & 204 & & 80 & \\
\hline
\end{tabular}

Table 2. Revenue of Non-ETOPS Flight 2016

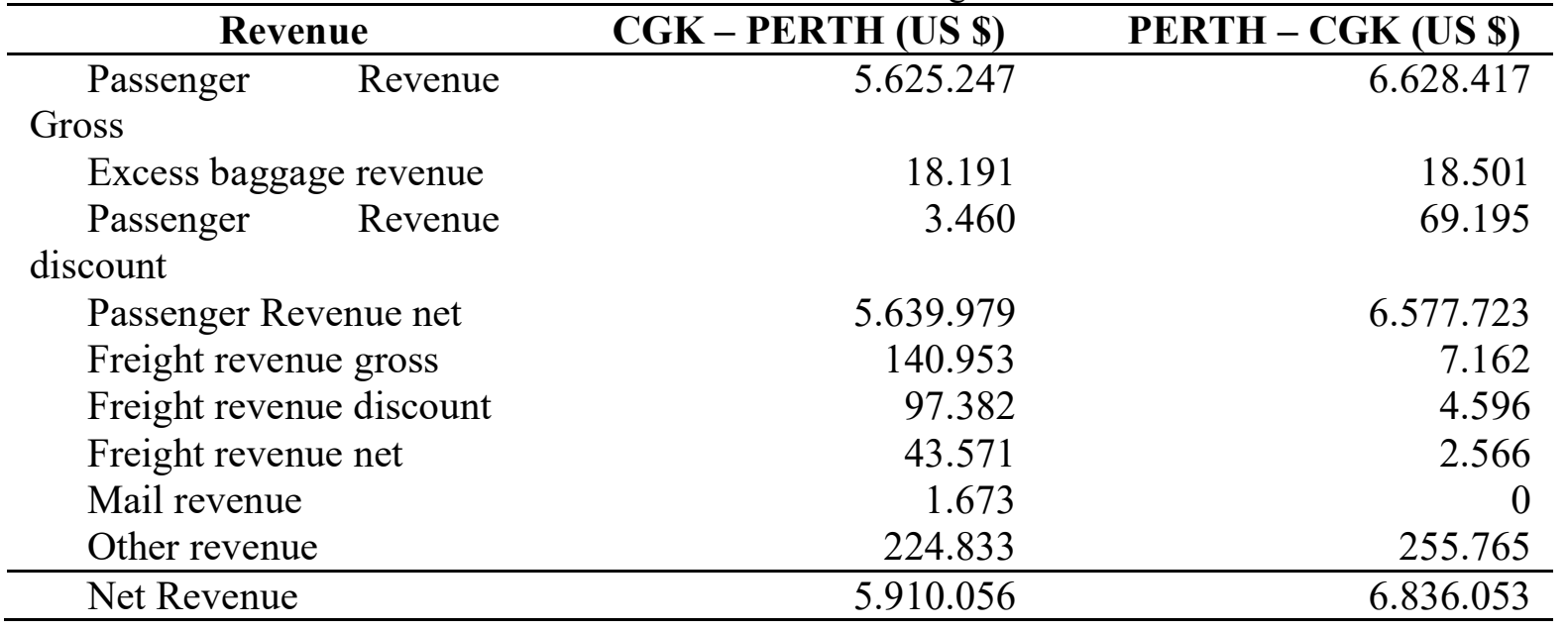

The flight cost or expenditure consist of many kinds of cost describe on Table 3. Direct traffic cost consist of passenger commission, freight commission, credit card commission, catering, on board service, and reservation cost paid by customers. Direct flight cost is the highest one.

The third stage is the valuation of the benefits and costs of ETOPS flight and NonETOPS flight. Cost planning required for Non-Etops and Etops for Cengkareng - Perth Cengkareng route was planned and revenue obtained in 2017 estimated. Several assumptions are 192 times flights in a year and 80\% load factor. Calculation of Etops and Non-ETOPS flight cost for Cengkareng - Perth - Cengkareng route only different on direct flight cost, fleet cost and pilot training cost. Direct flight costs on Non-Etops for Cengkareng - Perth route is USD 2.429.000 and ETOPS flight cost USD 2.391.000 
resulting a gap of USD 37.600. Direct flight cost for Perth - Cengkareng route Non-Etops was USD 2.834.000 and the Etops cost was USD 2.813.000 resulting gap of USD 20.000. Fleet cost only changed at the depreciation cost and lease cost of aircraft, while for the cost of insurance does not change. Fleet cost flight Non-ETOPS route Cengkareng - Perth was USD 1.266.000 and ETOPS flights cost USD 1.246.000 thus spending a gap of USD 20.000. Perth - Cengkareng flight route the Non-ETOPS fleet cost was USD 1.295 .000 and Etops was USD 1.283.000 resulting in a gap of USD 11.600.

Table 3. Comparison of Etops and Non-Etops Flight cost 2016

\begin{tabular}{|c|c|c|c|c|c|}
\hline \multirow{2}{*}{\multicolumn{2}{|c|}{ Cost }} & \multicolumn{2}{|c|}{ CGK - Perth } & \multicolumn{2}{|c|}{ Pert - CGK } \\
\hline & & $\begin{array}{r}\text { NON } \\
\text { ETOPS } \\
(\mathrm{USD})\end{array}$ & $\begin{array}{r}\text { ETOPS } \\
\text { (USD) }\end{array}$ & $\begin{array}{r}\text { NON } \\
\text { ETOPS } \\
(\mathrm{USD})\end{array}$ & $\begin{array}{r}\text { ETOPS } \\
\text { (USD) }\end{array}$ \\
\hline \multicolumn{2}{|c|}{ Direct Traffic Cost } & 774.963 & 774.963 & 954.956 & 954.956 \\
\hline \multicolumn{2}{|c|}{ Direct Flight Cost } & 2.428 .913 & $\begin{array}{r}2.391 .2 \\
51\end{array}$ & $\begin{array}{r}2.833 .7 \\
03\end{array}$ & 2.833 .703 \\
\hline \multicolumn{2}{|c|}{ Fuel Aircraft } & 1.203 .150 & 1.140 .5 & 1.203 .6 & 1.203 .648 \\
\hline Cockpi & Crew & 152.466 & 149.978 & $153.77 \hat{2}$ & 153.772 \\
\hline Cabin & Crew & 182.990 & 180.004 & 178.236 & 178.236 \\
\hline Landin & & 174.496 & 174.496 & 126.835 & 126.835 \\
\hline Handlir & & 196.978 & 196.978 & 610.744 & 610.744 \\
\hline Air & Traffic & 86.570 & 73.786 & 105.300 & 105.300 \\
\hline variable & & 432.259 & 475.485 & 455.164 & 455.164 \\
\hline Indirect Cos & & 205.855 & 205.855 & 213.809 & 213.809 \\
\hline Fleet Cost & & 1.266 .213 & 1.245 .8 & 1.295 .3 & 1.283 .720 \\
\hline Deprec & & 93.559 & 92.033 & $95.6 \hat{53}$ & 94.781 \\
\hline Lease $A$ & raft & 1.152 .300 & 1.133 .4 & 1.179 .2 & 1.168 .539 \\
\hline Insuran & & 20.354 & 20.354 & $20.3 \hat{9} \hat{9}$ & 20.399 \\
\hline Overhead C & & 396.218 & 396.218 & 437.631 & 437.631 \\
\hline Flight Interı & & 4.376 & 4.376 & 4.549 & 4.549 \\
\hline Administrat & $\mathrm{HO}$ & 358.697 & 358.697 & 415.996 & 415.996 \\
\hline Training $\mathrm{Co}$ & & - & 5.819 & 0 & 5.819 \\
\hline TOTAL CC & & 5.435 .235 & 5.383 .0 & 6.155 .9 & 6.150 .183 \\
\hline
\end{tabular}

Training cost is used for 1 pilot of Boeing 737 - 800 New Generation. The Cengkareng Perth route requires $25 \%$ of the total training cost. The pilot training cost for ETOPS flight is IDR 5 million for each person. Cengkareng - Perth - Cengkareng flight route alone requires $5 \%$ of the total 310 crew of Boeing $737-800$ New Generation or 31 crew. Total training cost for Cengkareng flight - Perth - Cengkareng for $31 \mathrm{crew}$ is IDR 155 million or if converted into dollars is USD 11,638.

The fourth stage compares the net benefits of each option. Cengkareng - Perth route revenue is USD 7.217.054 per year, then net benefit Non-ETOPS flight is USD 1.782.000 and ETOPS flights is USD 1.834.000. Perth - Cengkareng route gain potential revenue USD 8.291.000 per year and obtained a net benefit for Non-ETOPS flight USD 2.135.000 and Etops USD 2.141.000. The fifth stage is to identify the 'best' option. The choice of best 
option can be seen based on the largest net benefit from each route. Based on the largest net benefit for the Cengkareng - Perth - Cengkareng route, Etops is chosen as the best option compared to Non-ETOPS flights. Fuel that can be saved if using ETOPS is 185,806 liters per year or 192 times flight. Total cost saved is USD 57.969 per year. Table 5 outlines the overall flight costs of Non-Etops and ETOPS routes Cengkareng - Perth - Cengkareng.

Based on financial statements, the revenue earned from NON-ETOPS Cengkareng Perth flight in 2016 was USD 5,910,056 and Perth - Cengkareng was USD 6,836,053. Total revenue was USD 12.746.109. Table 5 give the total flight cost for NON ETOPS and for ETOPS. From the data we can make a calculation of benefit of flight and compare the benefit between ETOPS and NON ETOPS. Cost-benefit analysis shows that ETOPS flights are more profitable, although requires training costs for pilots. The benefit for 2016 NON ETOPS flight was 1.154.894 USD and for ETOPS was 1.212.863 USD. Although the used of ETOPS flight on 2016 not increase the benefit significantly, the flight for the route was increase in 2017. The estimation of load factor was $80 \%$ compare to $201660 \%$. In this case, the effect of use ETOPS flight will give profit increase significantly.

\subsection{Cost Structure Analysis}

The most influential cost of transportation business is fuel cost, it also happens on bus operational costs [1]. The result of cost structure analysis for Cengkareng-Perth route shows that direct flight cost is the biggest expenditure components for Non-ETOPS flight (44.69\%) and fleet cost are the biggest expenditure components for ETOPS flight (44.42\%). Etops flight decreased the direct flight cost $0.27 \%$, fleet cost $0.16 \%$, and need additional training cost $0.11 \%$ of all cost. The result for Perth - Cengkareng route also shows that direct flight cost and fleet cost as the largest cost components for Non-Etops and Etops. Etops flight result on a decrease of direct flight cost $0 \%$, fleet cost $0.17 \%$, and need additional training cost by $0.09 \%$. The most influential resource on Non-Etops and ETOPS flights is the fuel cost, describe Table 4.

Table 4. Comparison of Etops and Non-Etops Cost Structure

\begin{tabular}{lrrrr}
\hline & \multicolumn{2}{c}{ CGK - PER } & \multicolumn{2}{c}{ PER - CGK } \\
\cline { 2 - 5 } & \multirow{2}{*}{ Non etops } & \multicolumn{1}{c}{ Etops } & \multicolumn{1}{c}{ Non } \\
etops & \multicolumn{1}{c}{ Etops } \\
\hline Direct Traffic Cost & $14,26 \%$ & $14,40 \%$ & $15,51 \%$ & $15,53 \%$ \\
Direct Flight Cost & $44,69 \%$ & $44,42 \%$ & $46,03 \%$ & $46,03 \%$ \\
Indirect Cost & $3,79 \%$ & $3,82 \%$ & $3,47 \%$ & $3,48 \%$ \\
Fleet Cost & $23,30 \%$ & $23,14 \%$ & $21,04 \%$ & $20,87 \%$ \\
Overhead Cost & $7,29 \%$ & $7,36 \%$ & $7,11 \%$ & $7,12 \%$ \\
Flight Interrupted & $0,08 \%$ & $0,08 \%$ & $0,07 \%$ & $0,07 \%$ \\
Administration HO & $6,60 \%$ & $6,66 \%$ & $6,76 \%$ & $6,76 \%$ \\
Training Cost & $0 \%$ & $0,11 \%$ & $0 \%$ & $0,09 \%$ \\
\hline TOTAL COST & $100 \%$ & $100 \%$ & $100 \%$ & $100 \%$ \\
\hline
\end{tabular}

Cockpit crew travel and cabin crew travel are also one of the most cost-affecting aspects of cost. These costs are part of the direct flight cost group. Non-Etops and ETOPS flights also associated with fleet costs, and training costs. The efficiency or savings made by ETOPS flight can be seen from the percentage of direct flight cost, fleet cost, and overhead cost.

Based on the details of cost structure analysis, it is proven that fuel is the most influential component of direct flight cost. Fuel consumption difference between Non-Etops and 
ETOPS flight for Cengkareng - Perth route is 105 liters per year, and for Perth Cengkareng route is 80 liters per year. Thus, it can be concluded that by using Etops result on cost reduction from fuel savings caused by flight duration. Cost saving can be used for route-related marketing costs in order to increase load factor, improved quality of passenger care and increased service for passengers.

\section{Conclusions}

Cost-benefit analysis shows that ETOPS flights are more profitable than NON ETOPS. Compare to NON ETOPS, ETOPS flight requires training costs for pilots but saving the fuel consumption cost. Based on cost structure analysis, the greatest expenditure is direct flight cost component due to fuel cost. Fuel consumption difference between Non-Etops and ETOPS flight according to amount of distance reduction or time flight.

Analysis on ETOPS and NON ETOPS flight can be done more sensitive if we concern only on cost reduction result of fuel consumption decreasing. The revenue calculation significantly influence by load factor assumption and the calculation of revenue will give the same value for ETOPS and NON ETOPS flight model.

\section{References}

1. R. Purwaningsih., H. Nugroho., "Analysis of Public Transport Rates Based on Vehicle Operational Costs and Consumer Willingness to Pay (WTP)", Conference proceeding ICOMS 2016, Yogyakarta, Indonesia, (2016).

2. Transport Canada Safety and Security. Safety Criteria for Approval of Extended Range Twin-Operations (ETOPS). Canada, (1996).

3. South African Civil Aviation Authority. ETOPS Operations. South African, (2015).

4. L. Chester., M. Pandey., The New FAA ETOPS rule, Boeing Aero magazine, aero quarterly, Vol 2, (2007).

5. A. Osterwalder., Y. Pigneur., Business Model Generation. Jakarta: Elex Media Komputindo, (2012).

6. Morlok., K. Edward., Pengantar Teknik dan Perencanaan Transportasi, (Introduction to Transportation Planning Technique), Erlangga, Jakarta, (1988).

7. R. W. Boadway., The Welfare Foundations of Cost-Benefit Analysis: The Economic Journal. 84(336). 926-939, (1974).

8. A. K. Dasgupta. Cost-Benefit Analysis. In: Economic Theory and the Developing Countries. Palgrave: London, (1974).

9. F. Prasetya., Modul Ekonomi Publik Bagian VI: Analisis Biaya dan Manfaat. Malang: Universitas Brawijaya, (2012).

10. P. Holland., Simple Introduction to Cost-Benefit Analysis. Technical Support Services, Natural Resources Governance Unit, (2012). 